\title{
Collagenase specificity in chondrosarcoma metastasis
}

\footnotetext{
S.P. Scully,

K.R. Berend,

W.-N. Qi and

J.M. Harrelson
}

Division of O rthopaedics, Duke U niversity Medical Center, Durham, NC, USA

\author{
Correspondence \\ S.P. Scully \\ Division of O rthopaedics, DUMC \\ Box 3312 \\ Durham, NC 27710 \\ USA \\ Fax: + 1-919-681-7161 \\ E-mail: scull002@mc.duke.edu \\ Presented at the I International \\ Symposium on "Signal Transduction \\ and Gene Expression in Cell \\ Proliferation and Differentiation", \\ São Paulo, SP, Brasil, \\ August 31-September 2, 1998. \\ Research supported by \\ GlaxoW elcome \\ and K. Edwards.
}

Received November 12, 1998 Accepted December 14, 1998

\section{Abstract}

The treatment of some mesenchymal malignancies has made significant gains over the past few decades with the development of effective systemic therapies. In contrast, the treatment of chondrosarcoma has been limited to surgical resection, with the most significant prognostic indicators being surgical margins and histologic grade. We have reported that MMP-1/TIMP-1 gene expression serves to prognosticate for tumor recurrence in this group of patients. This led to the hypothesis that collagenase activity facilitates cell egression from the cartilaginous matrix. In the current study we examine the specificity of collagenase gene expression in archival human chondrosarcoma samples using semi-quantitative PCR. Messenger RNA was affinity extracted and subject to reverse transcription. The subsequent cDNA was amplified using novel primers and quantitated by densitometry. Ratios of gene expression were constructed and compared to diseasefree survival. The data demonstrate that the significance of the MMP1/TIMP-1 ratio as a predictor of recurrence is confirmed with a larger number of patients. Neutrophil collagenase or MMP-8 was observed in only 5 of 29 samples. Collagenase- 3 or MMP-13 was observed in all samples but the level did not correlate with disease-free survival. Since the collagenases have similar activity for fibrillar collagens and cleave the peptide in the same location, post-transcriptional regulatory mechanisms may account for the observed specificity. The determination of the MMP-1/TIMP-1 gene expression ratio not only serves to identify those patients at risk for recurrence but may also serve as a novel therapeutic avenue as an adjunct to surgical resection.

\section{Key words}

- Chondrosarcoma

- Metastasis

- Collagenase

- Gene expression

- Prognosis

\section{Introduction}

The ability to predict the biologic behavior of cartilaginous neoplasms has been difficult and many studies have sought to identify a marker for recurrence (1-23). We have reported that the MMP-1/TIMP-1 ratio serves as a prognostic indicator of survival in patients with chondrosarcoma (24). We hypothesized that the expression and activity of MMP-1, interstitial collagenase, allows the cell to egress the confines of the local cartilaginous tissue and gain access to the circulation, which in turn may lead to hematogenous metastasis. We now question the specificity of collagenase for this process and examine the other two known collagenases, MMP-8 and MMP-13, for prognostic significance in the recurrence of chondrosarcoma. 


\section{Material and Methods}

Patients with chondrosarcoma were treated by surgical resection as a primary means of disease control between 1979 and 1992. Of the patients treated 29 had archival paraffin-embedded specimens and adequate clinical history to enable the following study. Paraffin-embedded specimens were sectioned and ten $10-\mu \mathrm{m}$ sections were processed for mRNA isolation using Dynabeads oligo $(\mathrm{dT})_{25}$ and reverse transcribed with an oligo $(\mathrm{dT})_{16}$ primer. PCR was performed by

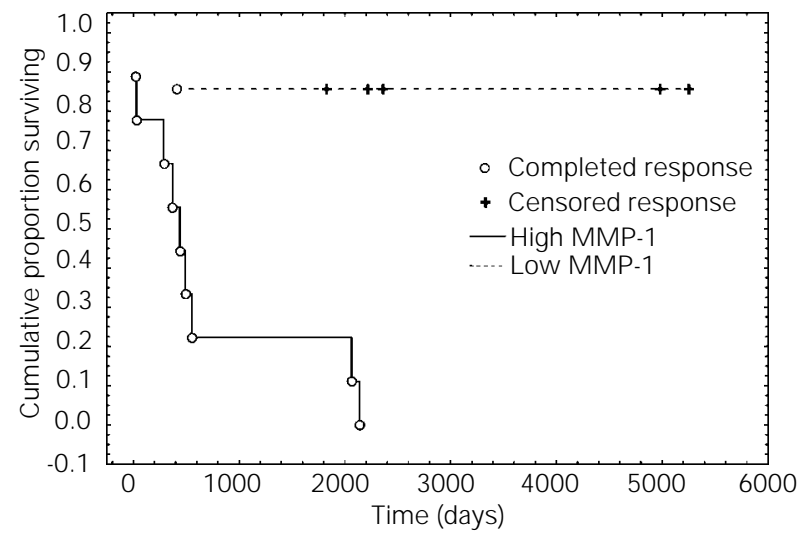

Figure 1 - The effect of MMP-1 gene expression on disease-free survival. Survival was statistically different between high and low expressers $(\mathrm{P}<0.0018)$.

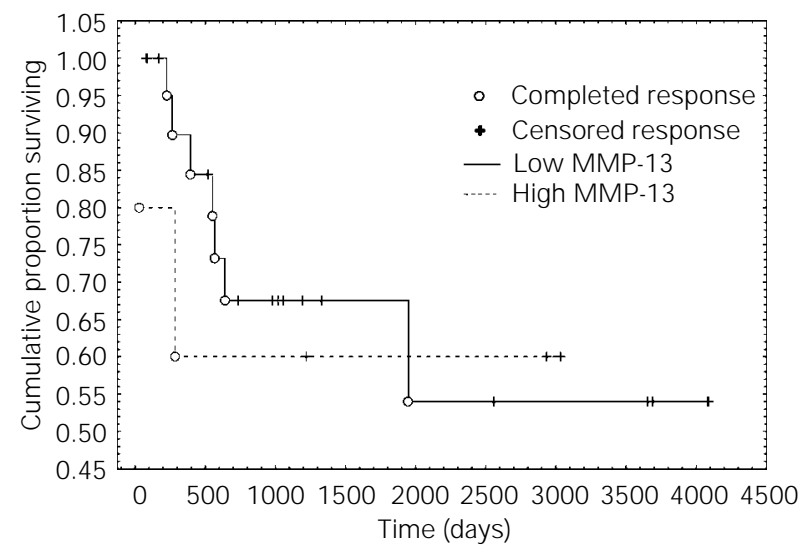

Figure 2 - The effect of MMP-13 gene expression on disease-free survival. Survival was not statistically different between high and low expressers $(P=0.788)$. using primers corresponding to novel sequences specific for MMP-1, MMP-8, MMP13, and TIMP-1. Digoxigenin-labeled PCR products were subjected to electrophoresis on agarose gels, and transferred to nylon membranes. Autoradiogram band intensity was quantitated by chemiluminescence and densitometry. MMP-1,8,13/TIMP-1 ratios were constructed as a means of measuring the proteolytic milieu of the tumor. Statistical significance determined by the KaplanMeier survival analysis and log rank analysis was used to assess the influence of MMP ratios on event-free survival. All experiments were carried out in triplicate.

\section{Results}

Twenty-nine patients with nonmetastatic disease were treated primarily with surgical resection of the primary chondrosarcoma with adequate surgical margins. Adjuvant radiation therapy or chemotherapy was not employed until such time that either a local or distant recurrence was observed. Of the 29 patients, 11 ultimately experienced a recurrence of their disease process.

In examining the gene expression for MMP-1, MMP-8, and MMP-13, we observed that all tumors expressed MMP-1 and MMP13 to a varying extent. Only five tumors expressed MMP-8 at levels detectable by PCR. The expression of MMP-8 did not correlate with survival in the patients in which it was detectable and suggested that this enzyme was not integral in the metastatic process. Analysis of MMP-1/TIMP-1 demonstrated a strong statistical significance with respect to event-free survival, $\mathrm{P}<0.0018$ (Figure 1). This ratio serves as an independent prognostic indicator of event-free survival in addition to histologic grade. The expression of MMP-13 was present in each tumor specimen examined. The MMP-13/TIMP-1 ratio gene expression did not correlate with eventfree survival in this patient population, $\mathrm{P}=$ 0.788 (Figure 2). 


\section{Discussion}

The prognostic significance that was previously reported for MMP-1/TIMP-1 was confirmed as the number of patients included in the study was increased and the statistical significance also increased. Others have noted the expression of MMP-1 in chondrosarcoma tissue by immunostaining but were unable to correlate its presence with metastatic potential (25-27).

Neutrophil collagenase was thought initially to be exclusively found in these cells. Subsequent studies have identified MMP-8 in articular cartilage and chondrocytes both at the gene expression level and at the protein level (28). Others have found increased expression of MMP-8 in osteoarthritic cartilage (29) and cleavage of aggrecan by this collagenase (30,31). MMP-8 expression was detectable in only five of 29 chondrosarcoma specimens and could not be correlated with disease recurrence. This collagenase is unlikely to play a central role in the metastatic process for these cells.

Collagenase-3 (MMP-13) is a matrix metalloproteinase involved in human breast cancer pathology and in arthritic processes. The C-terminal domain of collagenase- 3 has a similar structure to the equivalent domain of gelatinase $\mathrm{A}$ and fibroblast collagenase 1; however, its detailed structure and surface charge pattern have a somewhat greater similarity to the latter. It is proposed that several small structural differences may act together to confer the characteristic binding and cleavage specificities of collagenases for triplehelical substrates, probably in co-operation with a fitting interdomain linker (32). The expression of MMP-13 was present in every specimen examined; however, the level of expression did not correlate with the rate of recurrence. This is an interesting finding in that MMP-1 and MMP-13 cleave the collagen molecule in the same location, although MMP-13 demonstrates a second cleavage site (33-35). MMP-13 also demonstrates a higher activity for type II collagen than does MMP-1. Since the expression of MMP-1 has prognostic significance for recurrence in chondrosarcoma and the expression of MMP-13 does not, it may be that post-transcriptional regulation may lead to higher MMP-1 activity than MMP-13 activity in the pericellular environment. It has been reported that as a tumor dedifferentiates and becomes more aggressive biologically, there is a phenotypic drift that results in increased amounts of type I collagen being synthesized (36-39). It is possible that specificity for cleavage of type I collagen may be more important than that of type II collagen to permit cell egression and this is what leads to the observed results.

While the details of the complex regulation of collagenase activity remain to be unraveled in this disease process, it is clear that gene expression of MMP-1 provides a clear means of predicting which patients are at a higher risk of recurrence. With this as a tool, novel therapeutic strategies can be focussed on this group of patients. The specific inhibition of collagenase-1 activity in patients with chondrosarcoma may serve as the basis of a biologic adjuvant therapy and provide the first advance in therapy in several decades. 


\section{References}

1. Brien EW, Mirra J M \& Kerr R (1997). Benign and malignant cartilage tumors of bone and joint - their anatomic and theoretical basis with an emphasis on radiology, pathology and clinical biology. 1. The intramedullary cartilage tumors (Review). Skeletal Radiology, 26: 325-353.

2. Bridge J A, DeBoer J, Travis J , J ohansson SL, Elmberger G, Noel SM \& Neff J R (1994). Simultaneous interphase cytogenetic analysis and fluorescence immunophenotyping of dedifferentiated chondrosarcoma. Implications for histopathogenesis. American J ournal of Pathology, 144: 215-220.

3. Bridge J A, Bhatia PS, Anderson J R \& Neff $J R$ (1993). Biologic and clinical significance of cytogenetic and molecular cytogenetic abnormalities in benign and malignant cartilaginous lesions. Cancer Genetics and Cytogenetics, 69: 79-90.

4. Castresana J S, Barrios C, Gomez L \& Kreicbergs A (1992). Amplification of the c-myc proto-oncogene in human chondrosarcoma. Diagnostic Molecular Pathology, 1: 235-238.

5. Choong PFM, Rydholm A, Mertens F \& Mandahl N (1997). Musculoskeletal oncology - advances in cytogenetics and molecular genetics and their clinical implications (Review). Acta Oncologica, 36: 245-254.

6. Coughlan B, Feliz A, Ishida T, Czerniak B \& Dorfman HD (1995). p53 expression and DNA ploidy of cartilage lesions. Human Pathology, 26: 620-624.

7. Crim J R \& Seeger LL (1993). Diagnosis of low-grade chondrosarcoma. Radiology, 189: 503; discussion 504.

8. Dijkhuizen $T$, van den Berg $E$, Molenaar WM, Oosterhuis J W, Dam A, Wiersema J, Schraffordt Koops $\mathrm{H} \&$ de J ong $B$ (1994). Cytogenetics as a tool in the histologic subclassification of chondrosarcomas. Cancer Genetics and Cytogenetics, 76: 100-105.

9. Dobashi $Y$, Sugimura $H$, Sato $A$, Hirabayashi $T$, Kanda $H$, Kitagawa $T$, Kawaguchi N, Imamura T \& Machinami R (1993). Possible association of p53 overexpression and mutation with high-grade chondrosarcoma. Diagnostic Molecular Pathology, 2: 257-263.

10. Hasegawa T, Seki K, Yang P, Hirose T, Hizawa K, Wada T\& Wakabayashi J (1995). Differentiation and proliferative activity in benign and malignant cartilage tumors of bone. Human Pathology, 26: 838-845.
11. Helio H, Karaharju E, Bohling T, Kivioja A \& Nordling S (1995). Chondrosarcoma of bone. A clinical and DNA flow cytometric study. European J ournal of Surgical Oncology, 21: 408-413.

12. Larramendy ML, Tarkkanen M, Valle J, Kivioja AH, Ervasti H, Karaharju E, Salmivalli T, Elomaa I \& Knuutila S (1997). Gains, losses, and amplifications of DNA sequences evaluated by comparative genomic hybridization in chondrosarcomas. American J ournal of Pathology, 150: 685691.

13. Nawa G, Ueda T, Mori S, Yoshikawa H, Fukuda H, Ishiguro S, Funai H \& Uchida A (1996). Prognostic significance of Ki67 (MIB1) proliferation index and p53 overexpression in chondrosarcomas. International J oumal of Cancer, 69: 86-91.

14. Orndal C, Mandahl N, Rydholm A, Willen H, Brosjo O \& Mitelman F (1993). Chromosome aberrations and cytogenetic intratumor heterogeneity in chondrosarcomas. J ournal of Cancer Research and Clinical Oncology, 120: 51-56.

15. Rosier RN, Okeefe RJ, Teot LA, Fox EJ , NesterTA, Puzas J E, Reynolds PR \& Hicks DG (1997). P-Glycoprotein expression in cartilaginous tumors. J ournal of Surgical Oncology, 65: 95-105.

16. Scully S (1997). Prognostic markers in chondrosarcoma: evaluation of cell proliferation and regulators of the cell cycle. Sarcoma, 1: 79-87.

17. Shih CS, Wang LS, Yang SS, Fahn HJ , Wu LH, Chen WYK \& Huang MH (1996). DNA flow cytometric analysis of chest-wall chondroma and chondrosarcoma. Scandinavian J ournal of Thoracic and Cardiovascular Surgery, 30: 157-161.

18. Simms WW, Ordonez NG, J ohnston D, Ayala AG \& Czerniak B (1995). p53 expression in dedifferentiated chondrosarcoma. Cancer, 76: 223-227.

19. Sogawa K, Yamada T, Funamoto Y, Kohno K, Nishikawa H, Kishida F, Hamazaki F, Yamashita N \& Matsumoto K (1994). Selective increase in expression of isoform PP1 gamma 1 of type-1 protein phosphatase in chondrosarcoma cells. Research Communications in Molecular Pathology and Pharmacology, 86: 375-378.

20. Sogawa K, Yamada T, Oka S, Kawasaki K, Mori S, Tanaka H, Norimatsu H, Cai $Y$, Kuwabara H \& Shima H (1995). Enhanced expression of catalytic subunit isoform PP1 gamma 1 of protein phosphatase type 1 associated with malignancy of osteogenic tumor. Cancer Letters, 89: 1-6.
21. Swarts SJ, Neff J R, J ohansson SL \& Bridge J A (1996). Cytogenetic analysis of dedifferentiated chondrosarcoma. Cancer Genetics and Cytogenetics, 89: 49-51.

22. Wemer $M$, Rieck J, Heintz A, PosI $M \&$ Delling G (1996). Comparative DNAcytometric and cytogenetic determination of ploidy in chondrosarcomas and osteosarcomas (German). Pathologe, 17: 374-379.

23. Yamaguchi T, Toguchida J, Wadayama B, Kanoe $\mathrm{H}$, Nakayama T, Ishizaki K, Ikenaga M, Kotoura Y \& Sasaki MS (1996). Loss of heterozygosity and tumor suppressor gene mutations in chondrosarcomas. Anticancer Research, 16: 2009-2015.

24. Berend KBJ \& Scully SP (1998). Metalloproteinase gene expression as a prognostic indicator for survival in patients with chondrosarcoma. J ournal of Bone and J oint Surgery, 80A: 11-17.

25. Moses MA \& Shing Y (1994). Production of matrix metalloproteinases and a metalloproteinase inhibitor by swarm rat chondrosarcoma. Biochemical and Biophysical Research Communications, 199: 418-424.

26. Schoedel KE, Ohori NP, Greco A \& Steiner GC (1997). Expression of metalloproteinases and tissue inhibitor in cartilaginous neoplasms of bone. Applied Immunohistochemistry, 5: 111-116.

27. Kawashima A, Okada Y, Nakanishi I, Ueda Y, Iwata K \& Roessner A (1997). Immunolocalization of matrix metalloproteinases and tissue inhibitors of metalloproteinases in human chondrosarcomas. General and Diagnostic Pathology, 142: 129-137.

28. Cole AA, Chubinskaya S, Schumacher $B$, Huch K, Szabo G, Yao J , Mikecz K, Hasty KA \& Kuettner KE (1996). Chondrocyte matrix metalloproteinase-8. Human articular chondrocytes express neutrophil collagenase. J ournal of Biological Chemistry, 271: 11023-11026.

29. Shlopov BV, Lie WR, Mainardi CL, Cole AA, Chubinskaya S \& Hasty KA (1997). Osteoarthritic lesions: involvement of three different collagenases. Arthritis and Rheumatism, 40: 2065-2074.

30. Fosang AJ , Last K \& Maciewicz RA (1996). Aggrecan is degraded by matrix metalloproteinases in human arthritis. Evidence that matrix metalloproteinase and aggrecanase activities can be independent. J ournal of Clinical Investigation, 98: 2292-2299.

31. Arner EC, Decicco CP, Cherney R \& Tortorella MD (1997). Cleavage of native 
cartilage aggrecan by neutrophil collagenase (MMP-8) is distinct from endogenous cleavage by aggrecanase. J ournal of Biological Chemistry, 272: 9294-9299.

32. Gomisruth FX, Gohlke U, Betz M, Knauper V, Murphy G, Lopezotin C \& Bode W (1996). The helping hand of collagenase-3 (M mp-13) - 2.7 angstrom crystal structure of its C-terminal haemopexin-like domain. J ournal of Molecular Biology, 264: 556566.

33. Lemaitre $V$, J ungbluth $A \&$ Eeckhout $Y$ (1997). The recombinant catalytic domain of mouse collagenase-3 depolymerizes type I collagen by cleaving its aminotelopeptides. Biochemical and Biophysical Research Communications, 230: 202-205.

34. Mitchell PG, Magna HA, Reeves LM, Lopresti-M orrow LL, Yocum SA, Rosner PJ , Geoghegan KF \& Hambor J E (1996).
Cloning, expression, and type II collagenolytic activity of matrix metalloproteinase-13 from human osteoarthritic cartilage. J oumal of Clinical Investigation, 97: 761-768.

35. Knauper V, Lopez-Otin C, Smith B, Knight G \& Murphy G (1996). Biochemical characterization of human collagenase-3. J ournal of Biological Chemistry, 271: 15441550.

36. Ueda $Y$, Oda $Y$, Tsuchiya $H$, Tomita $K$ \& Nakanishi I (1990). Immunohistological study on collagenous proteins of benign and malignant human cartilaginous tumours of bone. Virchows Archiv. A, Pathological Anatomy and Histopathology, 417: 291-297.

37. Kawashima A, Ueda Y, Tsuchiya H, Tomita K, Nagai Y \& Nakanishi I (1993). Immunohistochemical localization of collagenous proteins in cartilaginous tumors: characteristic distribution of type IX collagen. J ournal of Cancer Research and Clinical Oncology, 120: 35-40.

38. Huang GQ \& Steiner GC (1989). Immunohistochemical localization of type II collagen in cartilage-forming tumors. Bulletin of the Hospital for J oint Diseases Orthopaedic Institute, 49: 94-102 (published erratum appears in Bulletin of the Hospital for J oint Diseases Orthopaedic Institute, 1990 Spring; 50(1): 69).

39. Aigner T, Dertinger S, Vornehm SI, Dudhia J , Vondermark K \& Kirchner T (1997). Phenotypic diversity of neoplastic chondrocytes and extracellular matrix gene expression in cartilaginous neoplasms. American J ournal of Pathology, 150: 2133-2141. 